\title{
Post-Merger Financial Performance of Indian Manufacturing Companies with Reference to Metals \& Metal Products and Machinery Companies
}

\author{
Mahamuni PN, Jumle AG \\ ZES's Zeal Institute of Business Administration, Computer Application \& Research (ZIBACAR), Narhe, \\ Pune, India
}

\begin{abstract}
This research work was undertaken to find out the impact of merger on the financial performance of Indian manufacturing industry with reference to selected metals and metal products and machinery companies during $1^{\text {st }}$ April 2005 to $31^{\text {st }}$ March 2010. In simple words, this study is all about to find out whether merger \& acquisition helps the organization in post-merger period to improve their performance in the sense like; companies achieved liquidity, solvency and improve profitability after merger, companies expand their business activities after merger, is there any improvement in operating performance of merged manufacturing companies and also an attempts to fill this gap in knowledge about M\&As in India.
\end{abstract}

KEYWORDS: Mergers, Acquisitions, Financial Performance

Corresponding author: P.U. Mahamuni, Email: pravinmahamuni@gmail.com 


\section{INTRODUCTION}

Mergers, acquisitions and corporate control have emerged as major forces in the modern financial and economic environment. Mergers, a source of corporate growth, have been the subject of careful examination by scholars. The mergers and acquisitions in India have changed dramatically after the liberalization of Indian economy. The policy of liberalization, decontrol and globalization of the economy has exposed the corporate sector to domestic and global competition. Low cost products, with good quality have become essential for a company to survive in the competitive market. Factors like low interest rates, cheap labor, and liberal government policy, have helped the Indian corporate sector to reduce their cost. It is in this context that corporate sectors view mergers for further cost reduction through technology advancement or to make their presence felt in the market. The liberalization policy of Government of India has witnessed an unprecedented number of mergers and acquisitions in the country. In terms of the growth rate in mergers and acquisitions deals, India occupies the second position in the world.

\section{Mergers and Acquisitions in Indian Industry}

In Indian industry, the pace for mergers and acquisitions activity picked up in response to various economic reforms introduced by the Government of India since 1991, in its move towards liberalization and globalization. The Indian economy has undergone a major transformation and structural change following the economic reforms, and "size and competence" have become the focus of business enterprises in India. Indian companies realised the need to grow and expand in businesses that they understood well, to face growing competition; several leading corporates have undertaken restructuring exercises to sell off non-core businesses, and to create stronger presence in their core areas of business interest. Mergers and acquisitions emerged as one of the most effective methods of such corporate restructuring, and became an integral part of the long-term business strategy of corporates in India. Over the last decade, mergers and acquisitions in the Indian industry have continuously increased in terms of number of deals and deal value.

A survey among Indian corporate managers in 2006 by Grant Thornton found that Mergers \& Acquisitions are a significant form of business strategy today for Indian Corporates. The three main objectives behind any M\&A transaction, for corporates today were found to be:

\section{$\checkmark \quad$ Improving Revenues and Profitability \\ $\checkmark \quad$ Faster qrowth in scale and quicker time to market \\ $\checkmark$ Acquisition of new technology or competence}

\section{Table No. 01: Objectives of Indian} Corporates for M\&As

\begin{tabular}{|l|c|}
\hline \multicolumn{1}{|c|}{$\begin{array}{c}\text { Objective behind the M\&A } \\
\text { Transaction }\end{array}$} & $\begin{array}{c}\text { Responses } \\
\text { (in \%) }\end{array}$ \\
\hline $\begin{array}{l}\text { To improve revenues \& } \\
\text { Profitability }\end{array}$ & $33 \%$ \\
\hline $\begin{array}{l}\text { Faster growth in scale and } \\
\text { quicker time to market }\end{array}$ & $28 \%$ \\
\hline $\begin{array}{l}\text { Acquisition of new technology } \\
\text { or competence }\end{array}$ & $22 \%$ \\
\hline $\begin{array}{l}\text { To eliminate competition \& } \\
\text { increase market share }\end{array}$ & $11 \%$ \\
\hline $\begin{array}{l}\text { Tax shields \& Investment } \\
\text { savings }\end{array}$ & $3 \%$ \\
\hline
\end{tabular}

Source: Grant Thornton, M\&A and Private Equity Scenario, 2006; India. 
Post-Merger Financial Performance of Indian Manufacturing Companies with Reference to Metals \& Metal Products and Machinery Companies

Given this context, the present study has attempted to examine the performance of companies that have gone through mergers in India, in the post-reforms period, and see if mergers had a significant impact on operating financial performance of merging companies. More specifically, the study has aimed to study mergers of firms in different industry sectors in India, to see if there are variations in the impact, for different industries.

\section{Significance}

This research effort is focused on mergers of Indian manufacturing industry with reference to selected Metals and Metal Products and Machinery companies during $1^{\text {st }}$ April 2005 to $31^{\text {st }}$ March 2010. In simple words, this study is all about to find out whether merger \& acquisition helps the organization in post merger period to improve their performance in the sense like; companies achieved liquidity, solvency and improve profitability after merger, companies expand their business activities after merger, is there any improvement in operating performance of merged manufacturing companies and also an attempts to fill this gap in knowledge about M\&As in India.

\section{OBJECTIVES OF THE STUDY}

1) To overview the operating performance of selected Indian Metals \& Metal Products and Machinery companies.

2) To evaluate the financial performance of selected Indian Metals \& Metal Products and Machinery companies during pre and post mergers.

3) To study the impact of merger on the financial performance of selected Indian
Metals \& Metal Products and Machinery companies in short run.

\section{REVIEW OF LITERATURE}

The following are the few existing studies reviewed which were conducted by researchers in the view of analyzing the financial performance during merger activity in different time periods.

Beena analysed the pre and post-merger performance of a sample of 115 acquiring firms in the manufacturing sector in India, between 1995-2000, using a set of financial ratios 4 and t-test. The study could not find any evidence of improvement in the financial ratios during the post-merger period, as compared to the preMerger period, for the acquiring firms. Pawaskar (10) analysed the pre-merger and post-merger operating performance of 36 acquiring firms during 1992-95, using ratios 5 of profitability, growth, leverage, and liquidity, and found that the acquiring firms performed better than industry average in terms of profitability. Regression Analysis however, showed that there was no increase in the postmerger profits compared to main competitors of the acquiring firms.

\section{Sinha N, Kaushik K P \& Chaudhary T} (2010): Measuring Post Merger and Acquisition Performance: An Investigation of Select Financial Sector Organizations in India - The present paper examines the impact of mergers and acquisitions on the financial efficiency of the selected financial institutions in India. The analysis consists of two stages. Firstly, by using the ratio analysis approach, we calculate the change in the position of the companies during 
the period 2000-2008. Secondly, we examine changes in the efficiency of the companies during the pre and post merger periods by using nonparametric Wilcoxon signed rank test. While we found a significant change in the earnings of the shareholders, there is no significant change in liquidity position of the firms. The result of the study indicate that M\&A cases in India show a significant correlation between financial performance and the M\&A deal, in the long run, and the acquiring firms were able to generate value.

Dube and Glascock (2006) examined the postacquisition differences in share and operating performance, and in risk characteristics, for acquirers who pay cash versus those who employ stock, as well as for acquirers who merge with targets as opposed to those who directly approach target shareholders to tender their shares.

Healy, Palepu, and Ruback examined postacquisition performance for 50 largest U.S. mergers between 1979 and 1984 by measuring cash flow performance, and concluded that operating performance of merging firms improved significantly following acquisitions, when compared to their respective industries.

Kruse, Park and Suzuki examined the longterm operating performance of Japanese companies using a sample of 56 mergers of manufacturing firms in the period 1969 to 1997. By examining the cash-flow performance in the five-year period following mergers, the study found evidence of improvements in operating performance, and also that the pre- and postmerger performance was highly correlated. The study concluded that control firm adjusted longterm operating performance following mergers in case of Japanese firms was positive but insignificant and there was a high correlation between pre- and post-merger performance.

\section{Pramod Mantravadi \& A Vidyadhar Reddy}

(2008): "Post-Merger Performance of Acquiring Firms from Different Industries in India" - This research study was aimed to study the impact of mergers on the operating performance of acquiring corporates in different industries, by examining some pre- merger and post-merger financial ratios, with the sample of firms chosen as all mergers involving public limited and traded companies in India between 1991 and 2003. The results suggest that there are minor variations in terms of impact on operating performance following mergers, in different industries in India. In particular, mergers seem to have had a slightly positive impact on profitability of firms in the banking and finance industry, the pharmaceuticals, textiles and electrical equipment sectors saw a marginal negative impact on operating performance (in terms of profitability and returns on investment). For the Chemicals and Agri-products sectors, mergers had caused a significant decline, both in terms of profitability margins and returns on investment and assets.

\section{Pramod Mantravadi and Vidyadhar Reddy} (2007) in their research study Mergers and operating performance: Indian experience, attempted to study the impact of mergers on the operating performance of acquiring corporate in different periods in India, after the announcement of industrial reforms, by examining some pre- and post-merger financial ratios, with chosen sample firms, and all mergers involving public limited and traded companies of nation between 1991 and 2003. The study results suggested that there are minor variations in terms of impact on operating performance following mergers in different 
Post-Merger Financial Performance of Indian Manufacturing Companies with Reference to Metals \& Metal Products and Machinery Companies

intervals of time in India. It also indicated that for mergers between the same groups of companies in India, there has been deterioration in performance and returns on investment.

Siriopoulos et.al. (2006): In their study of Mergers and Acquisitions in Greece also find that acquired firms are highly productive operations. These results support McGuckin \& Nguyen (1995) and Harris \& Robinson (2002) studies who have found that acquisition activity in the UK is generally associated with the transfer of firms with above average productivity. Since large firm size and high productivity are common characteristics of relatively mature targets, which have accumulated past experiences as a result of dynamic learning procedures, age of firm also emerges as a significant determinant variable of target firms in the study of Siriopoulos et.al. (2006). Overall, these studies favour rejection of the market for corporate control hypothesis.

Kaur S. compared the pre and post-takeover performance for a sample of 20 acquiring companies during 1997-2000, using a set of eight financial ratios 3, during a 3-year period before and after merger, using t-test. The study concluded that both profitability and efficiency of targeted companies declined in posttakeover period, but the change in post-takeover performance was statistically not significant.

\section{METHODOLOGY}

\section{Hypotheses of the Study}

The present study tests the following hypotheses.

The merged manufacturing companies did not improve liquidity, solvency and profitability after merger.
$>$ The merged manufacturing companies did not expand their business activities after merger.

$>$ There is improvement in operating performance of merged manufacturing companies.

\subsection{Sampling Design}

While selecting sample the researcher has used census survey method for determining \& selection of sample size for this study. After using this method researcher finalize 25 sample acquire firms which include 10 sample acquire firms from Metals \& Metal Products and 15 sample acquire firms from Machinery companies.

\subsection{Data Collection Method}

The present study is mainly based on secondary data. The collection of data \& information for the purpose of study are collected using CMIE Prowees Database \& Annual Report of the companies.

\section{RESULTS \& DISCUSSION}

\subsection{Analysis Approach}

The financial data are collected from CMIE Prowees Database Software for selected sample companies. The data is separated as per the various ratios as per requirement i.e. considering merger year as a base year which is denoted as 0 , Pre merger year taken as $-1,-2$ \& $3 \&$ Post 1, 2, \& 3. Further calculated the pre \& post means of selected various ratios and these means are used for doing paired sample' $t$ ' test.The approach of analysis is based on the level of agreement to the statement of 
hypotheses. The threshold of $\mathbf{5 0 \%}$ is considered to accept or refuse the hypothetical statement.

\section{Tools used for Data Analysis and Interpretation}

In order to analysis \& evaluation of the collected data, tools like Ratio Analysis, Mean, Standard Deviation \& paired sample ' $t$ '-test are used.

\section{Data Analysis \& Interpretations}

The results of the comparison of various parameters used for analysis of all sample merged firms in pre merger \& post merger have been portrays in above Table. It is observed that most of the parameters are decreased in post merger period. It has been explained with following financial parameters for the better understating the impact of M\&A on the financial performance of the all merged firms.

Liquidity Position [Current Ratio, Quick Ratio \& Net Working Capital]

In the post merger era the mean of Current Ratio (from 1.6004 to 0.6838) as well as Quick Ratio (from 0.8234 to 0.7997 ) is decreasing as compared to pre merger period. It seems that, merged firms are not in financial healthy after the post merger as compared to premerger. Hence, it recalls that, merged firms are insufficient assets available to pay liabilities after the merger, which indicates that incapable to paying its debts as they fall due. Whereas, Net working capital (from 154.1940 to 438.2633) of the sample merged firms are shown good improvement in it after the post merger period which indicates that they have more flexibility to spend on growing its business. Hence they required more working capital after the merger. It also gives an idea of company's efficiency. Money tied up in

Table No.02: Analysis of Metals \& Metal Products and Machinery Companies

\begin{tabular}{|l|r|r|r|r|}
\hline \multicolumn{1}{|c|}{ Parameters } & $\begin{array}{r}\text { Pre- Mean } \\
\text { (3 years before) }\end{array}$ & $\begin{array}{c}\text { Post- Mean } \\
\text { (3 years after) }\end{array}$ & 't' value & \multicolumn{1}{c|}{$\begin{array}{c}\text { 'p' value } \\
\text { (0.05) }\end{array}$} \\
\hline Current Ratio & 1.6004 & 0.6838 & 1.143 & 0.264 \\
\hline Quick Ratio & 0.8234 & 0.7997 & 0.281 & 0.781 \\
\hline Net Working Capital & 154.1940 & 438.2633 & -0.512 & 0.614 \\
\hline Debt-Equity Ratio & 0.7982 & 0.8737 & -0.462 & 0.648 \\
\hline Total Debt and Equity to Total Assets & 0.4531 & 0.5035 & -0.620 & 0.541 \\
\hline Total Borrowings and Equity to PBITDA & 4.1367 & 0.5914 & 0.722 & 0.477 \\
\hline Interest Coverage Ratio & 30.9384 & 35.5837 & -0.167 & 0.868 \\
\hline Operating Profit Ratio & 9.5603 & 8.9686 & 0.290 & 0.775 \\
\hline Net Profit Ratio & 5.4188 & 4.8012 & 0.499 & 0.623 \\
\hline Operating Profit Margin & 2.5700 & 3.1032 & -0.235 & 0.817 \\
\hline Gross Profit Margin & 9.5603 & 8.9686 & 0.290 & 0.775 \\
\hline Net Profit Margin & 5.1968 & 4.4043 & 0.643 & 0.526 \\
\hline Net Worth & 960.2549 & 2867.9595 & -2.003 & 0.057 \\
\hline Returns on Net worth & 21.8138 & 17.8302 & 1.078 & 0.292 \\
\hline Returns on Investment & 7.6734 & 6.9231 & 0.754 & 0.458 \\
\hline Returns on Capital Employed & 13.6569 & 12.9072 & 0.340 & 0.737 \\
\hline Capital Formation & 1568.5223 & 2579.5708 & -2.050 & 0.051 \\
\hline Increased Investment in Fixed Assets & 528.1664 & 1893.6543 & -1.246 & 0.225 \\
\hline
\end{tabular}


Post-Merger Financial Performance of Indian Manufacturing Companies with Reference to Metals \& Metal Products and Machinery Companies

inventory or accounts receivable cannot pay off any of the firms' short term financial obligations. Also they are not obtained 't' value at required probability level.

It is evidenced from the analysis that the null hypothesis - "The merged manufacturing companies did not achieve liquidity after merger" is fully accepted.

Solvency (Leverage) Position [Debt-Equity Ratio Total Debt and Equity to Total Assets, Total Borrowings and Equity to PBITDA \& Interest Coverage Ratio]

From the above analysis of the Table, it is referred that, there is slightly improvement in Debts-Equity Ratio (from 0.7982 to 0.8737 ) of average of all sample merged firms during the post merger period. Which indicating that they are able to builds a good reputation to the creditors after the merger in the sense that they has the ability to settle such obligation whenever it due.

The ratio of total debt and equity to total assets (from 0.4531 to 0.5035 ) is lower during pre merger period than that of post merger period. The growth of debt and equity to total assets of merged firms is statistically insignificant in above case. Also it clearly seems that sample merged firms are not able to cover their total debt and equity by total assets after the merger. Also, in the ratio of total debts and equity to PBITDA (from 4.1367 to 0.5914 ) it is decreased during the post merger period which reveals that there is increment shown in total debt \& equity but the PBDITA was not increased rather it is declined in post merger period this leads to incurred more debt after mergers and acquisitions. Where as the result of ' $t$ ' test shows that, in sample merged firms are insignificant at the required probability level, indicating that the decrease in total debts equity to PBITDA between pre and post merger is quite negligible.

The average of all sample merged firms' Interest Coverage Ratio is showing improvement in post merger period than of pre merger period. It indicates that sample firms are capable to pay its interest on outstanding debts very easily \& also afford to take more debts after the merger.

It is evidenced from the analysis that the null hypothesis - "The merged companies did not achieve better solvency after merger" is accepted.

Profitability Position: [Operating Profit Ratio, Net Profit Ratio, Returns on Investment and Net Worth]

From the analysis of above Table it is noted that, Operating Profit Ratio (from 9.5603 in pre merger \& 8.9686 in post merger period) \& Net Profit Ratio (from 5.4188 in pre merger \& 4.8012 in post merger period) are declined in post merger period. It seems that due merger \& acquisition activity increased in operating expenses in post merger period \& it reflects on decreased net profits of the sample companies in post merger period. Therefore this leads to declined in the Returns on Investment (from 7.6734 in pre merger \& 6.9231 in post merger period) during post merger period than during pre merger period. This indicates that sample merged firms have lesser ROI but not better ROI after merger. Whereas, the increased in Net Worth (from 960.2549 in pre merger \& 2867.9595 in post merger period) of the average mean of all merged firms, it confirms that sample merged firms improved their net worth after merger

It is evidenced from the analysis that the null hypothesis - "The merged manufacturing companies did not improve profitability after 
merger" is fully accepted. Because of the average mean of profitability of the entire sample merged firms have declined after the merger.

Operating Performance: [Operating Profit Margin, Gross Profit Margin, Net Profit Margi, Returns on Net Worth, Return on Capital Employed and Debt Equity Ratio]

The Operating Profit Margin (from 2.5700 in pre merger \& 3.1032 in post merger period) is increasing in post merger period which reveals that these firms are able to keep costs under control and also sales are increasing faster that costs, and is in a relatively liquid position after following the merger. But on the other side, it is observed that in Gross Profit Margin (from 9.5603 in pre merger \& 8.9686 in post merger period) \& Net Profit Margin (from 5.1968 in pre merger \& 4.4043 in post merger period) slightly decline in the margin during post merger period. It seems that sample merged firms are unable to improve profit after paying off its inventory cost, also shows inefficiency in using its labour and raw materials in the process of production and at more inefficient at converting sales into actual profit. This ultimately affects the liquidity position of the firm and also has less cash flow to spend on research \& development expenses, marketing or investing.

Whereas in Returns on Net worth (from 21.8138 in pre merger \& 17.8302 in post merger period) \& Returns on Capital Employed from 13.6569 in pre merger \& 12.907 in post merger period) average mean of all sample of merged firms' variation is lower in post merger period as compared to pre merge period. It confirms that due to merger \& acquisition the amount of net worth increased but then merged firms did not able to get required returns on net worth and also inefficiency in using its funds \& it reveals that management has shown inefficiency in using the investment and creditors into the business. Also are not obtained ' $t$ ' value at required probability level it can be said that the decrease in net margin ratio between pre \& post merger period is quite negligible.

Since from the above analysis, mergers were found to negatively impact the performance in terms of both profitability and returns on investment. This hypothesis, 'There is improvement in operating performance of merged manufacturing companies' is rejected,

Other Parameters: Capital Formation \& Increased Investment in Fixed Asset.

From the analysis of above Table, it is observed that, the average amount of capital formation (from 1568.5223 in pre merger \& 2579.5708 in post merger period) \& average amount of increased investment in fixed assets (from 528.1664 in pre merger \& 1893.6543 in post merger period) by mean of all sample merged firms is greater during post merger period than that of pre merger period. It is a clear proof that, those firms have undertaken expansion or modernization through increasing their investment in fixed assets and further their attempt after merger turn around positively which is a good sign because all sample merged firms improved their capacity after merger.

Therefore, the hypothesis, 'The merged companies did not expand their business activities after merger' is rejected. 
Post-Merger Financial Performance of Indian Manufacturing Companies with Reference to Metals \& Metal

\section{CONCLUSION}

It is quite clear from the study that firm gaze at M\&As due to the various factors as well as for expanding their market reach or as an entry strategy in the country or business segment. Some time it affected positively as well as negatively on the overall results of entire firms after the M\&As take place. It helps in the inorganic and quicker growth of the business of a firm. The decision to acquire or grow organically however depends on the business targets that the firms have set for themselves. In this scenario, M\&As have emerged as key growth drivers in the Indian manufacturing firms. However apart from this, it is extremely necessary for any firm to be consistent in tackling challenges the industry faces from time to time, failing which advantages of M\&A may not deliver the desired results.

\section{Limitations of the Study}

1) The study is mainly based on secondary data. The study is confined to only Indian manufacturing sector i.e. Selected Indian Metals \& metal Products companies \& Machinery Companies [25 companies (Metals \& Metal Products - 10 \& Machinery - 15) which are listed in BSE as well NSE, which have undergone mergers and acquisitions during 2005 to 2010.]

2) The study is undertaken only for the pre merger period of 3 years and post merger period of 3 years.

3) In the absence of more reliable data, CMIE data on M \& As are used in this study.

\section{Scope for further Research}

$\checkmark$ In this area could be an extension of the present study, by estimating and comparing with industry/sector averages, and the
Products and Machinery Companies differences, if any, could be explored further to derive further insights.

$\checkmark$ Researchers could also analyze impact of mergers and acquisitions on financial performance and correlate to shareholders' wealth of acquirer and acquiring firms.

$\checkmark$ The time frame for the study is pre 3 years pre-merger\& post 3 years post-merger. The study can be extended by considering at least 5 years pre-merger\& 5 years postmerger for getting the insight from long term point of view.

$\checkmark$ Most prominently, the study with similar objectives could be made from time to time.

\section{REFERENCES}

AGRAWAL A. JAFFE JF. \& MANDELKER GN. The post-merger performance of acquiring firms: a re-examination of an anomaly, Journal of Finance. 1992; Vol. 47, pp. 1605-21.

ANDRE P. KOOLI M. \& L'HER J. The longrun performance of mergers and acquisitions: evidence from the Canadian Stock Market", Financial Management. 2004; Vol. 33, pp. 2743.

BEENA PL. An Analysis of Mergers in the Private Corporate Sector in India", Centre for Development Studies, Thiruvananthapuram. 2000; Working Paper No 301.

CANAGAVALLY R. An Evaluation of Mergers and Acquisitions", M.Phil Dissertation (Unpublished), Pondicherry University, Pondicherry. 2000.

PATRO DK. TUCKMAN H. \& WANG X. Do mergers and acquisitions create shareholder wealth in the pharmaceutical industry? 
International Journal of Pharmaceutical and Healthcare Marketing. 2007. Vol. 1 No. 1, 2007, pp. 58-78.

SINHA N. KAUSHIK KP. CHAUDHARY T. Measuring Post Merger and Acquisition Performance: An Investigation of Select Financial Sector Organizations in India, International Journal of Economics and Finance. 2010; Vol. 2, No. 4; November 2010, 190-200.

GHOSH A. Does operating performance really improve following corporate acquisitions? Journal of Corporate Finance. 2001; 7 pp 151178

HEALY PM. PALEPU KG. \& RUBACK RS. Does corporate performance improve after mergers?, Journal of Financial Economics. 1992; Vol. 33 No. 2, pp. 135-76.

LODERER C. \& MARTIN K. Post-Acquisition Performance of Acquiring Firms, Financial Management. 1992; Vol 21, No 3, pp 69-79.

LUBATKIN M. Mergers and Performance of the Acquiring Firm, Academy of Management Review. 1983; Vol. 8, No. 2, April, pp 218-225

MARTYNOVA M. OOSTING S. \& RENNEBOOG L. The long-term operating performance of European Acquisitions, International Mergers and Acquisitions Activity since 1990: Quantitative Analysis and Recent Research, G.Gregoriou and L. Renneboog (eds.), Massachusetts: Elsevier. 2007; pp 1-40.

SELVAM M. BABU M. INDHUMATHI G. EBENEZER B. Impact of mergers on the corporate performance of acquirer and target companies in India" Journal of Modern
Accounting and Auditing. 2009; Vol.5, No.11 (Serial No.54)

GAUGHAN PA. Mergers, Acquisitions, and Corporate Restructurings, 2nd ed. New York: John Wiley \& Sons. 1999; 21-60.

MANTRAVADI P. \& REDDY A.V. PostMerger Performance of Acquiring Firms from Different Industries in India" International Research Journal of Finance and Economics. 2008; Issue 22: EuroJournals Publishing, Inc. 2008.

MAHAMUNI PN \& JUMLE AG. Measuring Post Merger Operating Performance of Acquiring Firms of Food \& Beverages Industries in India, Published in Pezzottaite Journals, International Journal of Retailing \& Rural Business Perspectives, A Refereed Quarterly Journal. 2012; 2279-0934 \& 22790942

VANITHA S. \& SELVAM M. Financial Performance of Indian Manufacturing Companies During Pre and Post Merger International Research Journal of Finance and Economics. 2007; Issue 12 EuroJournals Publishing, Inc.

SIDHARTH S \& SUNIL G. Comparison of Post-Merger performance of Acquiring Firms (India) involved in Domestic and Cross-border acquisitions MPRA. Paper. 2009; No. 19274.

KAUR S. A Study of Corporate Takeovers in India, Ph.D Dissertation (Unpublished), University of Delhi, New Delhi. 2002. 